\title{
DE
} DE GRUYTER OPEN

\section{LOCATION OF OPENING-OUT CROSS-CUTS IN RELATION TO ROCKBURST HAZARD CONDITIONS ALONG THE FACE IN THE LIGHT OF MODEL TESTING}

\author{
LOKALIZACJA PRZECINEK ŚCIANOWYCH A RYZYKO TĄPNIĘCIA NA WYBIEGU FRONTU \\ W ŚWIETLE BADAŃ MODELOWYCH
}

\begin{abstract}
The paper outlines the main objectives of the method used for assessment of rockburst hazard during longwall mining operations taking into account factors expressing the confined work conditions. Relying on analytical approach, the conditions are examined that are likely to trigger the rockburst occurrence along the face, with regards to the location of cross-cuts and taking into account the presence of past excavation and geological disorders in the overlying strata. Simulation data apply to three cases of model loading, representing the impacts of residual pillars, gobs surrounded by undisturbed blocks of coal and the presence of faults, whilst the procedure involves five possible locations of opening-out cross-cuts in relation to characteristic points in the model. Results are examined basing on variability patterns of stress concentration and energy density distribution in the proximity of the workface in the course of progressing mining operations.
\end{abstract}

Keywords: underground mining, confined conditions, natural hazards, rockbursts

W artykule przedstawiono główne założenia wykorzystanej metody oceny stanu zagrożenia tapaniami towarzyszącego wybieraniu złoża pokładowego systemem ścianowym z uwzględnieniem oddziaływania elementów opisujących skrępowane warunki prowadzenia robót. Wychodząc z rozważań analitycznych analizie poddano kwestie związane z możliwością wystapienia tąpnięcia na wybiegu frontu eksploatacyjnego w funkcji usytuowania wyrobisk startowych względem pozostawionych w warstwach nadbudowy typowych zaszłości eksploatacyjnych lub zaburzeń geologicznych. Zaprezentowano rezultaty symulacji komputerowych dla trzech schematów obciążenia modelowego ilustrującego wpływ filara resztkowego, zrobów otoczonych caliznami i uskoku o dużym zrzucie z uwzględnieniem pięciu różnych lokalizacji przecinek ścianowych w stosunku do punktów charakterystycznych modelu. Dyskusję wyników prowadzono w oparciu o rozkłady zmienności współczynnika koncentracji naprężeń oraz gęstości energii generowanej w otoczeniu frontu w konsekwencji rozwoju eksploatacji.

Slowa kluczowe: eksploatacja podziemna, warunki skrępowane, zagrożenia naturalne, tąpania

* AGH UNIVERSITY OF SCIENCE AND TECHNOLOGY, FACULTY OF MINING AND GEOENGINEERING, AL. A. MICKIEWICZA 30, 30-059 KRAKOW, POLAND 


\section{Introduction}

Due to a variety of geological and mining factors and gradual depletion of economically recoverable coal deposits in Polish collieries, mining conditions are expected to become more complicated and difficult each year. In consideration of fire, methane and climatic hazards as well as relevant underground and surface structure protection requirements, mining companies will have to mine very deep seams, in the proximity of residual structures and closures, near protecting pillars, in the gob-affected zones, on panel margins, and in the proximity of sedimentation discontinuities and tectonic structures (faulting). All these create most adverse conditions for mining whilst the risk of potentially hazardous occurrence of dynamic processes is anticipated to show a growing tendency despite certain stabilisation in recent years (Chlebowski, 2013). In the context of effectiveness of long-term preventive measures to be put in place, of particular importance is the location of opening- out headings, in the widely applied mining systems these include longwall cross-cuts. Their location can be optimised already at the stage of mining layout planning basing on rockburst hazard assessment data, including the assessment of risk involved in future mining in this area.

\section{Conceptual and theoretical backgrounds of rockburst hazard assessment}

Relying on the assumption that factors likely to give rise to rockbursts include the state of stress in the proximity of mine workings as well as the properties of the medium and induced seismicity of the rock strata, the horizontal stress component in the coal bed is obtained recalling a modified longwall mining model assuming the cylindrical bending of plates on the deformed surface (Fig. 1). Roof strata (Young modulus $E_{s t}$, thickness $\left.F_{s t}\right)$, floor strata $\left(E_{s p}, F_{s p}\right)$ characterised by the equivalent bending rigidity $(E J)$ and gobs (width $2 L_{p}$, Young modulus $E_{p}$ ) are treated as linearly deformable media whilst the coal seam is governed by the model of a nonlinearly deformed body $\left(E_{w}, M_{w}, h_{w}\right)$ and its full post-critical stress characteristics is approximated by straight line segments. It is assumed that roof bending above the coal seam being mined is caused by the acting bending moment whilst the influence of the working space on its magnitude is determined by the normative load bearing capacity of powered supports. A tri-axial state of stress

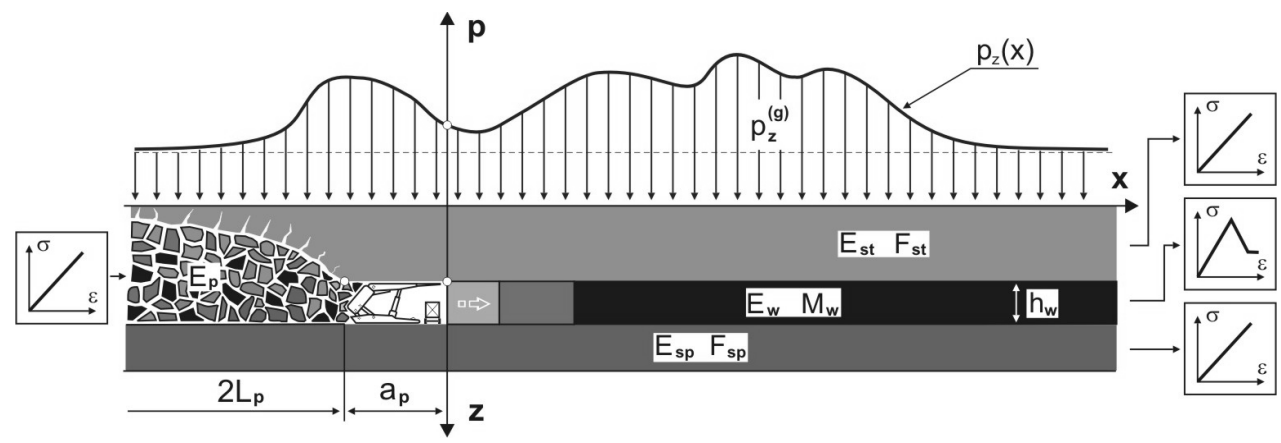

Fig. 1. Model of the longwall mining system 
is assumed to act in the coal seam, though in the applied 2D model the stress field is assumed to exhibit uni-directional longitudinal heterogeneity. In consideration of the registered impacts of residual features and faults, manifested as additional and not fully defined static loads, the model is proposed governing the loads acting upon the strata in the proximity of the longwall face whereby the horizontal stress $\left(p_{x}(x)\right)$ and vertical stress $\left(p_{z}(x)\right)$ distributions are treated as non-uniform.

Relying on the two-phase rockburst mechanism involving the fracturing of a certain volume of the rock medium followed by displacement of disintegrated rocks towards the hollows, the conditions for the rockburst occurrence were formulated basing on the energy conversion balance (Kłeczek et al., 1987; Zorychta, 2002) in the rock strata during the mining operations, expressed as:

$$
A_{z}+A_{d}-A_{p}-A_{k}-A_{s}-A_{r}=0
$$

With regards to proportions of particular kinds of energy, it appears that the resultant seismic energy reaching the gallery $\left(A_{s}\right)$, a derivative of elastic energy accumulated in the rockburst centre and of energy dispersed $\left(A_{r}\right)$ into plastic strains, will be by two orders of magnitude lower than kinetic energy $\left(A_{k}\right)$ involved in a rockburst. Thus, apart from the proportion of kinetic energy whose zero threshold triggers the dynamic event, all energy conversion processes are assumed to involve external energy $\left(A_{z}\right)$ resulting from secondary stress concentration around the excavation, dynamic energy $\left(A_{d}\right)$ expressing the rockburst impacts, and absorbed energy $\left(A_{p}\right)$ associated with work performed during rock failure. Therefore, the condition of rockburst occurrence, treated as the process of stability loss (Zorychta, 2002, 2003; Bukowska, 2002; Chlebowski, 2013), can be expressed by the system of inequalities:

$$
\begin{gathered}
A_{z}+A_{d} \geq A_{p}^{\max } \\
p_{z}^{(g)}+p_{p}(0) \geq R_{c}^{r}
\end{gathered}
$$

which also involves pre-mining gravity-induced stress $\left(p_{z}^{(g)}\right)$, additional external loads acting upon the workface $\left(p_{p}(0)\right)$ and residual compression strength $\left(R_{c}^{r}\right)$ of the coal block. In consideration of the two-phase rockburst mechanism, the condition is imposed whereby a rockburst occurrence requires the formation of the fracturing zone so that further analyses should be based on the Coulomb-Mohr yield criterion.

\section{Scope and results of analytical modelling}

With the progress of mining operations, the width of excavations (parameter $2 L_{p}$ in Fig. 1) will gradually increase, leading to an increase in external energy. These conditions prevail also in the event when the only acting loads are gravity-induced. It can be demonstrated that there exists a certain width of an excavation for which an increase in working pressure and energy supplied to the coal body in the neighbourhood of the longwall face will stabilise (developed exploitation). In order to investigate the influence of the excavation width, several case studies of undeveloped exploitation are analysed. The parameter $\left(2 L_{p}\right)$ determines the relevant components of the state of stress and potential elastic energy and thus controls the rockburst hazard level. The analytical procedure relied on variability distributions of relevant parameters in the function of the horizontal coordinate of the face location $\left(x_{o}\right)$, whilst their values were related to those obtained 


\section{4}

in the pre-mining conditions when gravity-induced rock stress distributions were uniform. The dimensionless stress concentration factors considered in this study include:

- for vertical stresses: $\quad k_{\sigma}\left(x_{o}\right)=\sigma_{z}(x=0) / \sigma_{z}(x \rightarrow \infty)$,

- external energy density: $k_{A}\left(x_{o}\right)=A_{z}(x=0) / A_{z}(x \rightarrow \infty)$.

This study does not aim at developing quantitative assessment criteria of rockburst hazard (as these should also concern geotechnical conditions), its main focus is to highlight qualitative dependencies between relevant parameters, taking into account the factors responsible for confined work conditions. In the context of the governing model of the rock strata and the condition of rockburst occurrence, the cases were considered which demonstrate the rockburst-prone behaviour of the roof strata - coal seam - floor strata system and the values of stress and strain parameters were selected such as to implicate the limited capability of the coal block to absorb elastic energy under the predefined external loading conditions.

Stability loss associated with a rockburst occurs when external energy becomes equal or higher than energy which can be absorbed by the coal body during the process of rock fragmentation, otherwise the system will maintain its static equilibrium despite progressing disintegration of the coal seam. The key parameter in the analysis is the external energy density and it is assumed that the moment when an event occurs is the derivative of the equality of the two energy types mentioned before. Three specific cases of analytically defined loading models were considered, associated with the impacts of:

- residual pillar $150 \mathrm{~m}$ in width (model \#1, Fig. 2),

- gob areas spanning over $150 \mathrm{~m}$, surrounded by undisturbed coal blocks (model \#2, Fig. 3),

- tectonic faults with the throw precluding their intersecting the workface (model \#3, Fig. 4).

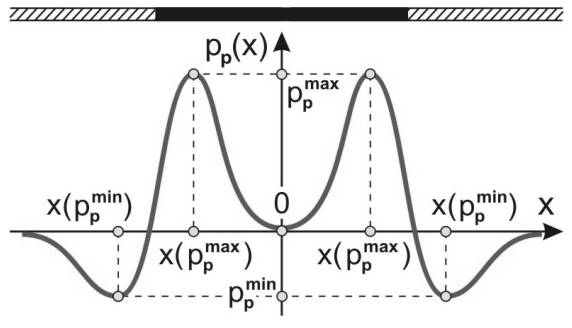

Fig. 2. Schematic of additional external loads - model \#1

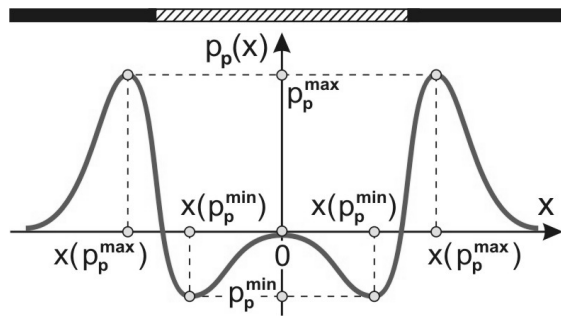

Fig. 3. Schematic of additional external loads - model \#2

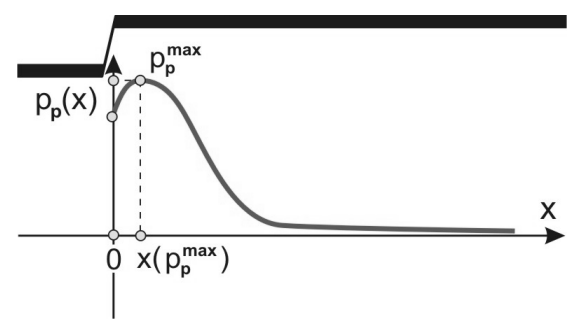

Fig. 4. Schematic of additional external loads - model \#3 
For the sake of comparison, model loading situations involving the pillar and gob areas were identical both in terms of the impact zone, their locations and extreme values of residual stress. The values of maximal relief factor and stress concentration on the roof horizon were taken to be identical $\left(p_{p}{ }^{\max } / p_{z}{ }^{(g)}=1, p_{p}{ }^{\min } / p_{z}^{(g)}=1\right)$ and their shift in the right direction towards the edge $\left(x\left(p_{p}{ }^{\max }\right), x\left(p_{p}{ }^{\mathrm{min}}\right)\right)$ is about $17 \mathrm{~m}$. The local minimum stress in the pillar axis and the maximum in the axis of the gob area was set to be equal to $10 \%$ of gravity-induced loads. In the case of a fault, the maximal acting load, equal to $150 \%$ of $p_{z}^{(\mathrm{g})}$, is registered at the distance of $25 \mathrm{~m}$ from the faulting plane and tends to gradually decrease with distance, reaching the value $0,01 p_{z}{ }^{(\mathrm{g})}$ at the point distant from the faulting plane by $150 \mathrm{~m}$. The calculation procedure was conducted for the coal seam with the thickness $h_{w}=3 \mathrm{~m}$, assuming the quotient of the elasticity modulus $\left(E_{w}\right)$ and the post-failure modulus $\left(M_{w}\right)$ was equal to unity and that the ratio of uniaxial compression strength $\left(R_{c}\right)$ to pre-mining gravity-induced loads $\left(p_{z}{ }^{(g)}\right)$ was 8 . The effects of horizontal stresses were taken into account assuming the value of the lateral thrust $(\lambda)$ to be 0,25 .

The mining sequence in the adopted simulation procedure was such that the positions of opening-up cross-cuts could be varied with respect to the characteristic points of the model loading, in order to investigate the vertical stress component and the generated external energy in the function of the excavation width which increases with the progress of mining operations. A single value of strain modulus for the excavation $\left(E_{p}\right)$ is assumed and the starting point in each run of the simulation procedure is a specific case selected such that the burst-prone behaviour should occur during mining operations commenced beyond the region affected by additional stresses.

\subsection{Mining under the residual pillar (model \#1)}

Locations of the opening-out cross-cuts with respect to characteristic points on the static load distribution patterns modelling the impacts of gob areas are as follows:

- beneath the gobs, in regions affected by gravity-induced loads only (longwall start point: $-300 \mathrm{~m})$,

- in locations corresponding to the border line between gob areas and undisturbed strata (longwall start point: $-75 \mathrm{~m}$ ),

- in the axis of the remaining rest pillar (longwall start point: $\pm 0 \mathrm{~m}$ ),

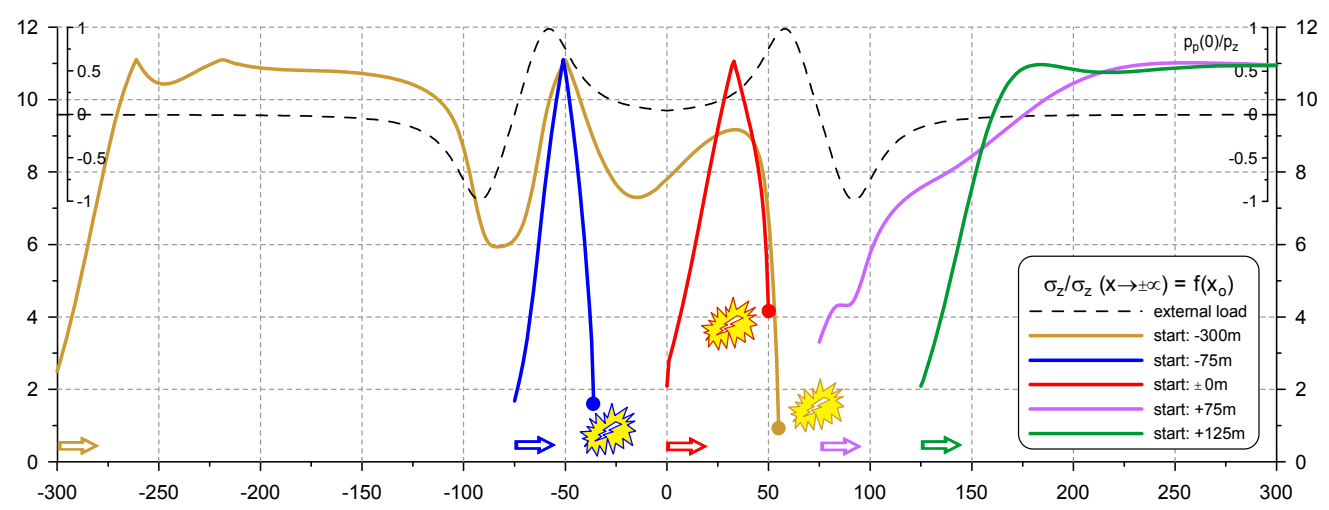

Fig. 5. Stress concentration under the pillar (model \#1) 
- in locations corresponding to the border line between undisturbed strata and gob area (longwall start point: $+75 \mathrm{~m}$ ),

- beneath the gobs, in the region where impacts of pillar-induced stress cease (longwall start point: $+125 \mathrm{~m})$.

Simulation data are summarized in the form of plots of vertical stress concentration (Fig. 5) and external energy density (Fig. 6).

To facilitate interpretation of results, the location where longwall operations begin (opening the workface) in each case is indicated with an arrow in the neighbourhood of a relevant $y$-axis coordinate. Plots illustrate the variability patterns of relevant parameters, also providing the schematics of modelled external loading (thin broken line) against the coordinate system whose horizontal axes for all plotted curves coincide whilst the abscissa is defined separately in upper corners. Of particular importance is the point of stability loss i.e. rockburst (when it occurs) and the face range that is associated with this event (indicated with a graphic symbol).

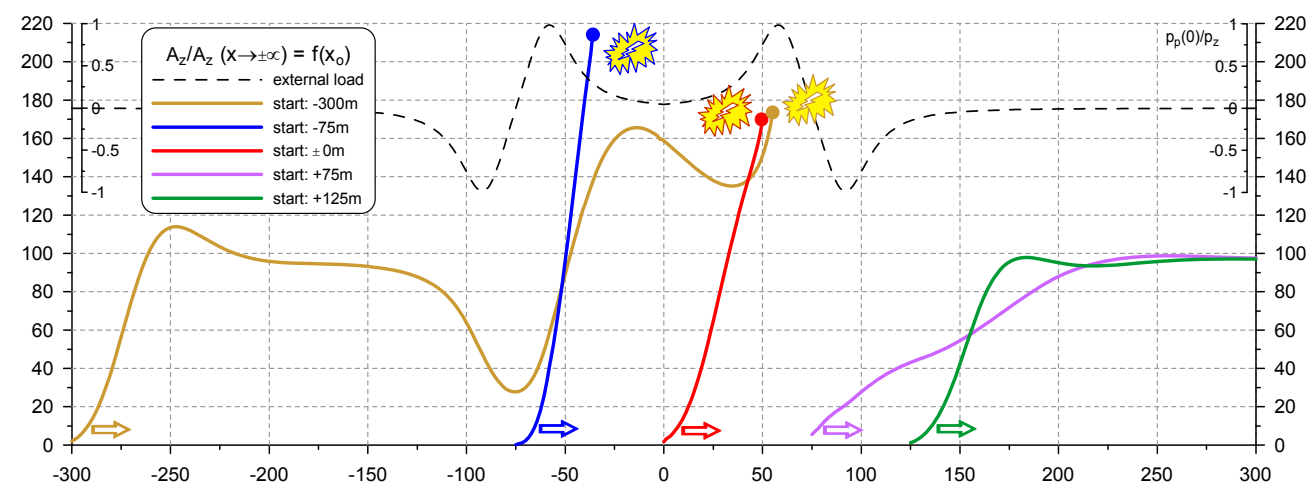

Fig. 6. External energy density underneath the pillar (model \#1)

It appears (see plots in Fig. 5, 6) that depending on the location where mining begins with respect to the position of elements disturbing the initial equilibrium condition in the strata, the rockburst risk level experienced during longwall operations should vary. Among five cases considered in the study, a rockburst should not occur when two mining layouts are chosen (longwall start point: $+75 \mathrm{~m},+125 \mathrm{~m})$. Of particular interest are two symmetrical variants associated with the longwall start from the locations corresponding to the gob-coal block boundary (longwall start point: $-75 \mathrm{~m}$ ) and the coal block- gobs boundary (longwall start point: $+75 \mathrm{~m}$ ). Even though the initial stress and energy levels are comparable in these two cases, the gradients of these parameters in the longwall start phase are different, which leads to different stress behaviour of these two media. In the first case the pre-mining cohesion of the deposit structure is disturbed, causing the external energy to systematically increase with progressing mining, finally reaching the ultimate value that the coal body is able to absorb and leading to a rockburst when the face range is approximately equal to $40 \mathrm{~m}$. The latter case illustrates the loading situation whereby the elastic behaviour on the face front ensures the static equilibrium condition over the entire face range, precluding the rockburst occurrence. That indicates that although the actual location of a cross-cut will impact on the rockburst hazard levels during ongoing mining operations, it 
is not the only factor triggering the rockburst occurrence. Beside geomechanical properties of the rock medium, other factors include the load distribution in the proximity of the developed workface, or specifically, the mode and range and stress variations in term of their impacts on the coal blocks, workface zone and gob areas.

\subsection{Mining under gob areas (model \#2)}

In physical terms, the investigated loading situations are the same as in the study of pillar mining with respect to the diagram of external loads:

- underneath the coal body, in the regions affected by gravity-induced loads only (longwall start point: $-300 \mathrm{~m}$ ),

- in locations corresponding to the gob-coal block boundary (longwall start point: $-75 \mathrm{~m}$ ),

- in the axis of the gob space (longwall start point: $\pm 0 \mathrm{~m}$ ),

- at locations corresponding to the coal block-gob boundary (longwall start point: $+75 \mathrm{~m}$ ),

- beneath the coal block, where stresses induced by the boundary on the right should cease (longwall start point: $+125 \mathrm{~m}$ ).

Simulation data are summarised in the form of plots of vertical stress concentration and (Fig. 7) and external energy density distributions (Fig. 8).

A thorough scrutiny of simulation results leads us to the conclusion that in the context of rockburst hazard, the values of the two analysed parameters are more favourable that in the model \#1 (pillar). Two out of five loading situations lead to the stability loss in connection with the actual location of a cross-cut, in the first case (longwall start point: $-300 \mathrm{~m}$ ) the region considered free from impacts of the previous mining operations and treated as the reference as no direct impacts of the gobs were registered would give rise to a rockburst occurrence also in the model considered in previous sections. The second case (longwall start point: $+75 \mathrm{~m}$ ) is that when mining begins at the gob-coal block boundary and a rockburst will occur when the excavation width reaches $40 \mathrm{~m}$ whilst the fracturing zone in the workface appears when the face range is about $20 \mathrm{~m}$.

For the remaining three localities of the opening-out cross-cuts, the face start gives rise to a less significant increase of external energy ensuring the static equilibrium in the coal seam roof-floor strata system.

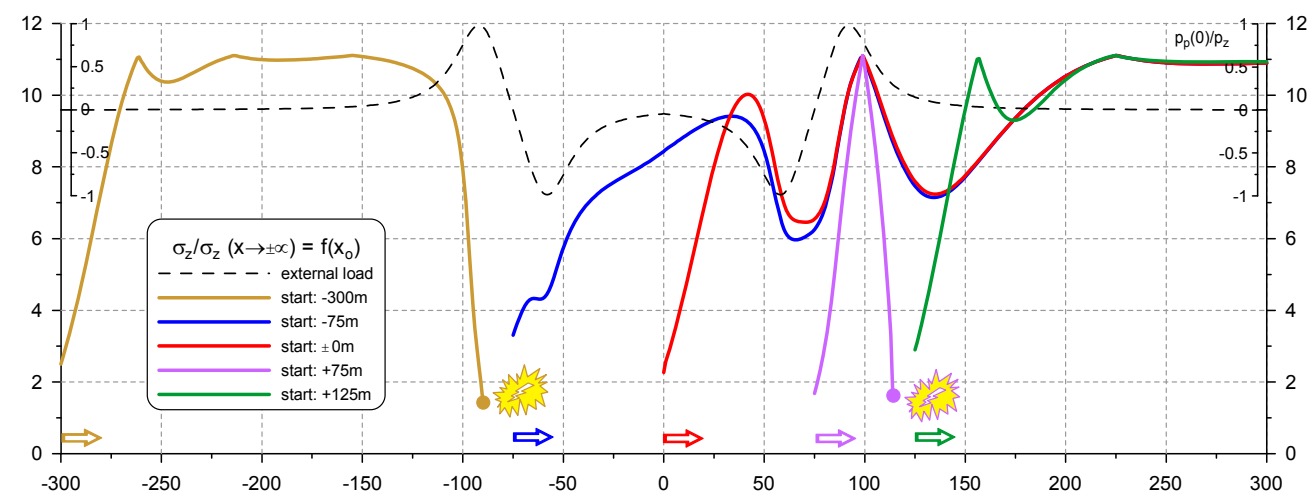

Fig. 7. Stress concentration beneath the gob areas (model \#2) 


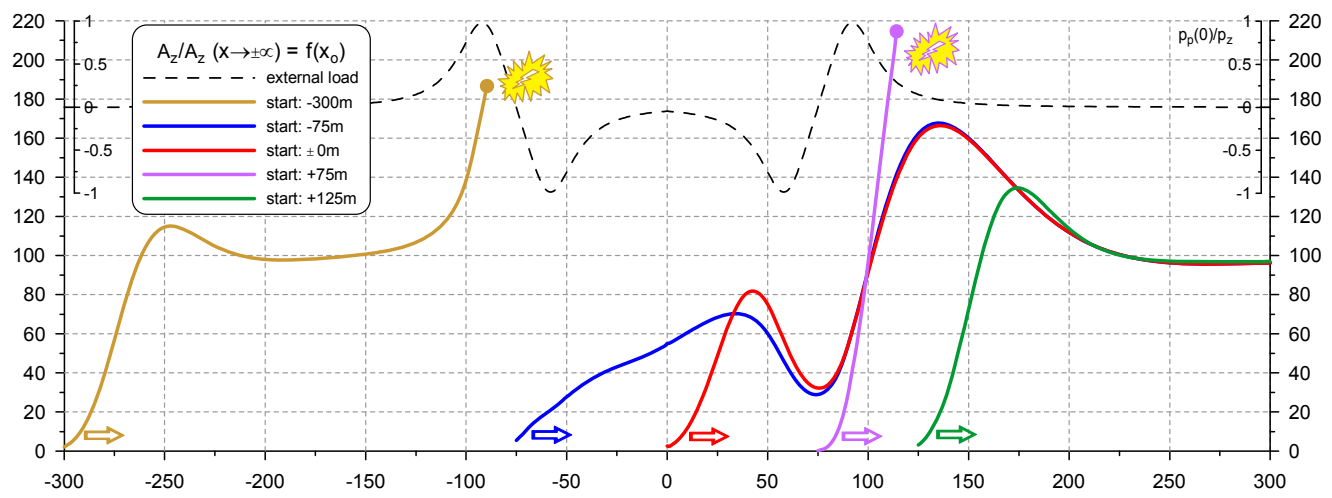

Fig. 8. External energy density underneath gob areas (model \#2)

Beside the rockburst occurrences, the plots reveal a nearly identical effect whereby a closerange and gradually vanishing rock disintegration zone within the coal body will continue along a long section of the face range, far from the impacts of additional static loads. This phenomenon can be interpreted as the coal seam's response to non-uniform load distribution in the gob area, however when the conditions for an rockburst occurrence are met, this situation will result in stability loss in the case of additional static loading or a dynamic behaviour being a consequence of a seismic event.

\subsection{Mining in the proximity of a fault (model \#3)}

The simulated mining strategy whereby workface is developed in the direction further from the faulting zone is considered to be more favourable in terms of involved dynamic processes. The following locations of the opening-out workings were considered:

- directly in the wake of the fault plane (longwall start point: $\pm 0 \mathrm{~m}$ ),

- at the distance between $50 \div 150 \mathrm{~m}$ from the fault plane (longwall start point: $+50 \mathrm{~m}$, $+75 \mathrm{~m},+100 \mathrm{~m},+150 \mathrm{~m}$, respectively).

As in the previous case, the registered parameters included the vertical stress concentration factor (Fig. 9) and external energy density (Fig. 10).

It is readily apparent that with increasing distance between the longwall start point and the fault, modelled as a disturbance with a large thrust amplitude, the stress distributions are modified and corrected whilst energy generated in the initial phase of face development is lower.

It can be clearly seen that in the predefined model situations, the least favourable conditions in terms of a rockburst hazard prevail when the opening-out cross-cuts are located at the distance of less than $50 \mathrm{~m}$ from the faults. Actually, a more accurate value of the critical limit could be established through further simulations. In the first two cases considered here (longwall start point: $\pm 0 \mathrm{~m},+50 \mathrm{~m}$ ) a rockburst occurs when the width of the excavations is $16 \mathrm{~m}$ and $20 \mathrm{~m}$, respectively. When the distance is $75 \mathrm{~m}$, then starting from $20 \mathrm{~m}$ of the face range, mining operations continue in the fracture zone stretching over $2 \mathrm{~m}$. In the other two cases (longwall start point: $+100 \mathrm{~m},+150 \mathrm{~m}$ ) the coal seam in the neighbourhood of the working face remains 


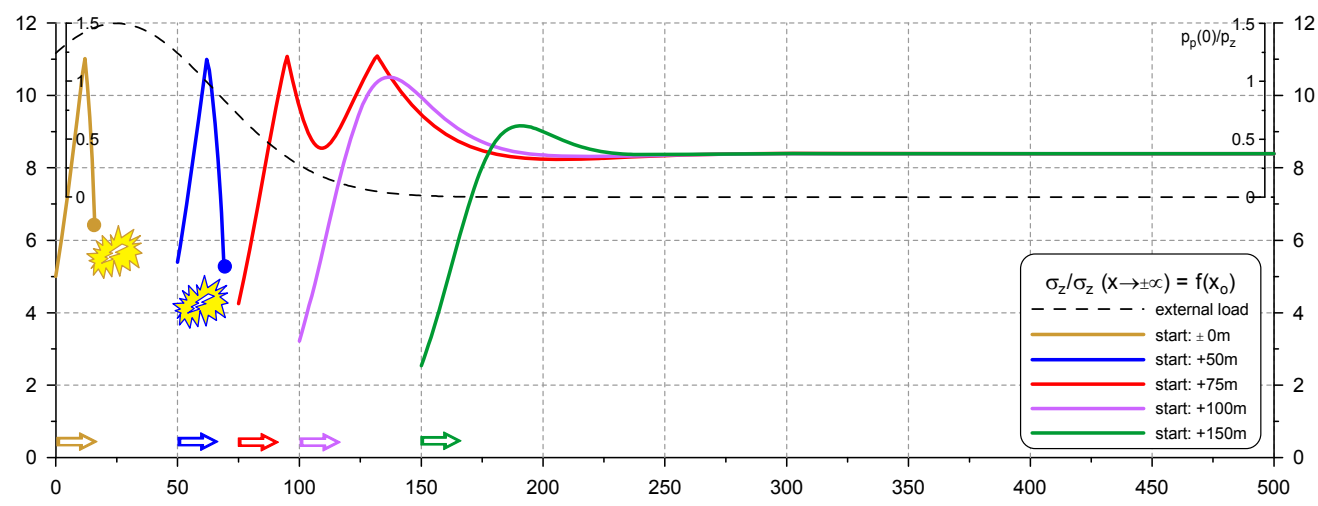

Fig. 9. Stress concentration in the proximity of a fault (model \#3)

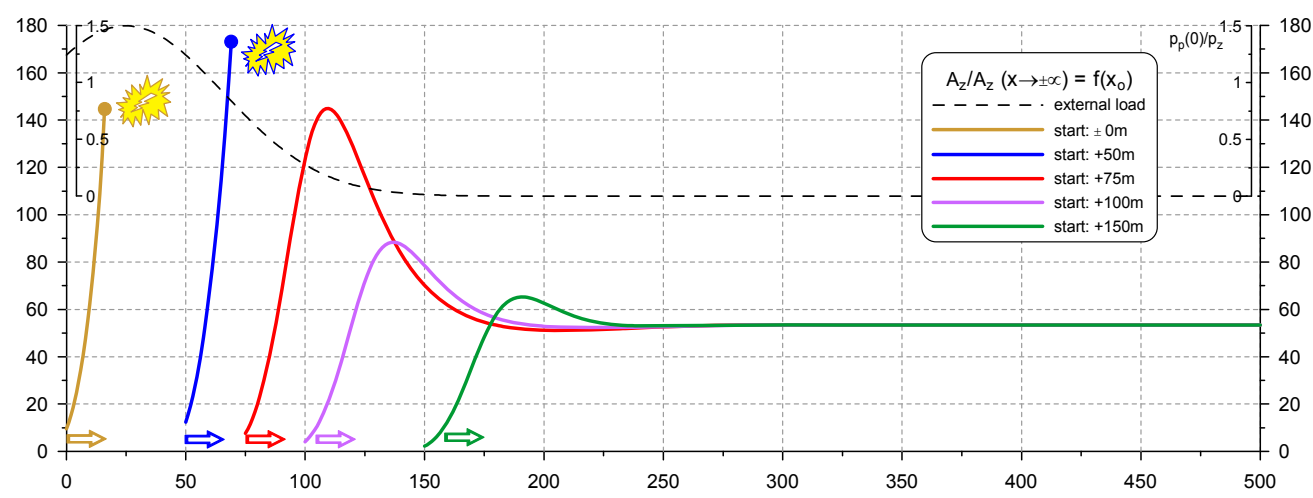

Fig. 10. External energy density in the proximity of a fault (model \#3)

elastic during the mining operations and in the last variant the only acting loads are pre-mining, gravity-induced stresses.

\section{Conclusions}

The study provides the theoretical backgrounds of the modelling method used for assessment of rockburst - probe behaviour and summarises the results of the computer-assisted procedure for simulating various layout options in mining a multiple seam coal deposit and assessing the involved rockburst hazard. The procedure uses analytical functions expressing additional loading to model the impacts of three elements which determine the coal seam's behaviour and produce confined geological and mining conditions: a residual pillar (model \#1), gob areas surrounded by undisturbed coal blocks (model \#2) and a high-thrust fault (model \#3). The main focus of this work was to establish how one aspect to be considered in mining layout design (location of the opening-out cross-cuts) should affect the rockburst hazard level. Discussion of results is based 
on distributions of stress concentration and density of energy generated in the proximity of the workface as the mining operations were in progress.

Theoretical considerations and the registered numerical data lead us to the following general conclusions:

- non-homogeneous state of stress in the rock strata due to the impacts of previous mining operations and tectonic faulting gives rise to non-uniform energy distributions, manifested as zones with different rockburst hazard ratings,

- in the stress concentration zones, load-induced processes differing in mode and scale are likely to begin in the coal seam and that, alongside the external energy increase, gives rise to elevated rockburst risk levels on the workface range,

- regardless of the loading model assumed to reflect the degree of confined working conditions, the span of the excavation has a major bearing on stress-energy distribution in the proximity of the workface and the lowest rockburst risk levels are associated with the start of the face operation,

- careful planning of the cross-cuts' layout allows the state of stress and external energy levels induced in the initial phase of mining operations to be controlled to a certain degree, thus enabling an indirect control of rockburst hazard levels,

- the design of the layout of the starting points for mining operation ought to consider all parameters of the system and the projected directions of mining operations in relation to the gobs, residual coal bodies or tectonic discontinuities.

Underlying the theoretical considerations summarised in the study were numerical simulation data, yet the authors ventured no conclusions in quantitative terms. Basing on averaged geotechnical parameters and considering typical loading situations and system geometries, mining operations were modelled to highlight a general relationship between the locations of openingout cross-cuts and the rockburst hazard level. To develop quantitative assessment criteria a more individual approach should be required because the stress variations along the coal bed horizon, and hence the rockburst hazard levels, are the functions of local geological and mining conditions, properties of the rock media, and the rockburst hazard indicator would have to consider seismicity data as well as the mining methods.

\section{References}

Bukowska M., 2002. Geomechaniczne własności skał w aspekcie zagrożenia tąaniami. Archives of Mining Sciences, vol. 47, no 2. Wydawnictwo PAN, Kraków.

Chlebowski D., 2013. Analityczne modelowanie eksploatacji skrępowanej w aspekcie identyfikacji stref zagrożonych tapaniami. Rozprawy-Monografie, nr 290. Wydawnictwo AGH, Kraków.

Kłeczek Z., Małoszewski J., Parysiewicz S., Zorychta A., 1987. Geomechaniczne kryteria zagrożeń tapaniami przy eksploatacji pokładów węgla kamiennego. Wydawnictwo GIG (seria dodatkowa), Katowice.

Zorychta A., 2000. Rock bursts in the light of the catastrophe theory. Arch. Min. Sci. 45, 1.

Zorychta A., 2002. Tapnięcie jako proces utraty stateczności wyrobiska podziemnego. Materiały IX międzynarodowej konferencji naukowo-technicznej Tąpania 2002. Wydawnictwo GIG, Katowice.

Zorychta A., 2003. Geomechaniczne modele górotworu tapiącego. Biblioteka Szkoły Eksploatacji Podziemnej (seria z perlikiem), nr 7. Wydawnictwo IGSMiE PAN, Kraków. 